\title{
Measuring the impact of customer satisfaction on profitability: A sectoral analysis
}

Received (in revised form): 17th August, 2001

\section{Matthew C. H. Yeung}

is currently studying for a PhD at the University of Nottingham. He is based at the University's Malaysian campus where he is a research fellow in the Centre for Europe-Asia Business Research (CEABuR). His main research interests relate to customer satisfaction issues and econometrics and statistical methods applied to marketing. He was previously based at Lingnan University in Hong Kong which he joined as a research assistant in 1998. He left Lingnan at the end of 1999 to concentrate full time on his PhD research at Nottingham University Business School.

\section{Christine T. Ennew}

is Academic Director of the Division of Business and Management at the University of Nottingham in Malaysia and Professor in the Business School at the University of Nottingham. She is also a research fellow in the Centre for Europe-Asia Business Research (CEABuR). Her research interests lie primarily in the area of services with a particular interest in the financial services sector, although she has also been active in research relating to the financing of small business and agricultural and food marketing. She is editor of the International Journal of Bank Marketing and is author of a range of academic and non-academic books and articles on the subject of marketing.

\begin{abstract}
Customer satisfaction is probably one of the most frequently measured marketing constructs, with most major organisations regularly collecting data on the extent to which their customers are satisfied. This level of interest is perhaps unsurprising given that it is a basic principle of marketing that business performance is enhanced by satisfying customers. The challenges of measuring satisfaction effectively had been extensively researched and there is a growing body of evidence to support the argument that satisfied customers are more loyal. There is rather less evidence to support the proposition that satisfaction contributes to business performance, not least because of the difficulties associated with relating consumer attitudes and behaviour to financial measures of performance as well as the intervening effects of loyalty. This paper focuses exclusively on satisfaction and uses aggregate measures from the American Consumer Satisfaction Index (ACSI) for companies across a range of sectors. It provides mixed evidence for the positive, impact of satisfaction on business performance using a range of different financial measures.
\end{abstract}

Christine Ennew Nottingham University Business School, Jubilee Campus, Wollaton Road, Nottingham NG8 1BB, UK.

Tel: +44 (0)115 9515259; Fax: $+44(0) 1158466686$ e-mail: Christine.Ennew@ Nottingham.ac.uk

\section{INTRODUCTION}

Academic and practitioner interest in consumer satisfaction has increased dramatically over the past two decades. Customer satisfaction measures have become an important element of competitive benchmarking, a business objective and a standard for performance measurement. A 1994 survey of more than 200 of the largest American companies (conducted by a leading total quality consulting organisation), indicated that over 90 per cent regularly measured and attempted to manage customer satisfaction. ${ }^{1}$ Equally, among the best manufacturing plants in North America, 96 per cent were regularly conducting customer satisfaction surveys. ${ }^{2}$ Although 
in some contexts, consumer satisfaction may be seen as an end in itself, for most businesses it is a means to an end with that end being enhanced performance. ${ }^{3}$ The link between satisfaction and performance is simple. Satisfied customers are thought to be more likely to repeat purchase (loyalty) and since loyal customers are thought to be cheaper to service (and less price sensitive) the expected result should be lower costs (and higher revenues) and thus higher profit. Through the effect on costs and revenues (and any additional business created via positive word of mouth) there should be a positive impact on business performance. The importance of the loyalty construct in this relationship should not be underestimated and a growing number of researchers suggest that in many cases, satisfaction may be primarily a hygiene factor, with loyalty being a key driving force for financial performance. ${ }^{4,5}$ While the complexity of the relationship between marketing variables and financial performance must be acknowledged, satisfaction continues to be an important and widely measured outcome for marketing managers and one which is expected to have an impact on profitability via its effects on retention. ${ }^{6,7}$

Evidence for the nature and magnitude of satisfaction's effect on business performance remains limited. Research on the service profit chain and research based around various aggregate customer satisfaction indices has provided some supportive evidence. The current paper seeks to contribute further to knowledge about satisfaction-profitability links by examining aggregate and sectoral level models using a range of different measures of financial performance including both organisationally and capital market generated measures. The strength of such an approach is that it provides a broader perspective on the importance of customer satisfaction than would be obtained by focusing only on individual companies or consumers. The paper begins with a short discussion of relevant literature to establish the current state of knowledge regarding satisfaction and performance (with a particular emphasis on financial performance). The subsequent section discusses the characteristics of the data used, namely the American Customer Satisfaction Index (ACSI) and Compustat financial data. Results for models estimated at an aggregate level and also at sectoral level are then presented and the final section of the paper offers some conclusions.

\section{CUSTOMER SATISFACTION AND ITS IMPACT ON PROFITABILITY}

Most definitions of marketing stress (either implicitly or explicitly) that it is a process that is concerned with improving business performance through the delivery of long-term customer satisfaction. Satisfied customers are more likely to be loyal and loyal customers are more profitable. Proponents of the service-profit chain would generalise this and highlight the importance of employee satisfaction in order to generate customer satisfaction. In either case, the causal mechanism runs from individual attitudes and behaviour through to organisation-level performance. Empirical estimation of these relationships therefore requires that attitudes and behaviour are somehow aggregated to the same unit of measurement as business performance (ie to the level of the organisation) or alternatively that business performance is disaggregated to the level of the individual customer.

The problems associated with trying to relate individual attitudes and behaviour to organisation-level performance have meant that much of the empirical work to date has focused on relationships between the various individual attitudes 
and behaviour. Thus, for example, there is strong evidence for the link between customer satisfaction and customer loyalty $^{8-11}$ and between quality/ satisfaction and retention. ${ }^{12-15}$ Relating these individual level measures to performance has generally been more problematic because of the difficulties associated with measuring profitability (or any other relevant performance measure) at the level of the consumer.

Although micro-level studies predominate, some macro-level evidence does exist. Many of the earlier studies focused attention on quality but the development of the ACSI paved the way for other studies more specifically concerned with satisfaction. At a very anecdotal level, the work of Peters and Waterman $^{16}$ attempts to provide some evidence for the financial benefits of delivering to a high level of quality while Mahajan, Sharama and Netmeyer ${ }^{17}$ explore the impact of quality on financial performance but rely on expert opinion rather than consumer experiences. Aaker and Jacobson ${ }^{18}$ used aggregate quality measures for 100 leading US brands and found evidence for the impact of quality on financial performance even after controlling for a range of other marketing and non-marketing measures. Anderson, Fornell and Lehman ${ }^{19}$ also provide evidence for the positive impact of satisfaction on profits using data from the Swedish Customer Satisfaction Barometer and ROI for the sample firms using both a lagged and a differenced specification. More recently, Loveman ${ }^{20}$ reports evidence that is supportive of the service profit chain in general based on attitudinal and behavioural data aggregated to the level of bank branch. In contrast, a survey of vice presidents of quality for major US firms conducted by Ittner and Larcker, ${ }^{21}$ suggested that only 28 per cent could relate their customer satisfaction measures to accounting returns and only 27 per cent to stock returns. Similarly, both Reichheld ${ }^{22}$ and Hofmeyr and Rice ${ }^{23}$ have cautioned against too much emphasis on satisfaction, arguing that satisfaction is in some senses a relatively passive state. Thus, it is not in itself sufficient to generate the active response associated with the conscious decision by a customer to repurchase and to demonstrate loyalty through, for example, positive word-of-mouth, commitment to a company or brand. This perspective would suggest the existence of a weak or perhaps low level relationship between satisfaction and financial performance with the stronger relationship existing between loyalty and financial performance.

This brief review of relevant literature suggests that evidence for the beneficial impacts of customer satisfaction on profitability is still relatively limited and that the nature of the relationship may be open to debate. Within existing studies that have examined the satisfaction-performance (profitability) link, a number of issues may warrant further examination. The first relates to the issue of measurement. Clearly, one area for debate is the choice of measures of financial performance given the different interpretation and significance of these measures. Organisationally-based measures (sales, profit, market share) have been used in some studies; capital market performance measures in others. The latter may be more forward looking when contrasted to the former; organisational measures may demonstrate whether satisfaction actually has had an impact in the past whereas capital market measures may provide insights relating to expected future benefits. Secondly, at the micro level, there are indications that the nature of many of the relationships between customer attitudes and behaviour may vary across industries. ${ }^{24-26}$ Whether this 
also applies in terms of performance impacts is less certain but clearly an issue that may be of some significance both academically and practically.

With these points in mind, the empirical analysis which forms the basis of this paper has three objectives; first, to provide further evidence on the impact of satisfaction on business performance; secondly to analyse the relationship systematically for a range of different performance measures and thirdly to examine the extent to which there may be sectoral variation in the estimated relationships. In particular the analysis will focus on internal measures of financial performance which are defined as those directly associated with and calculated by the firm (eg turnover) and external financial performance which is defined as stock market assessments of the firm.

\section{DATA AND METHODOLOGY}

The aims of the current paper and the focus on different measures of performance create a need for firm level measures of satisfaction rather than individual measures. Measures of financial performance were collected from a proprietary financial database, namely Standard and Poors' CompuStat, while aggregate measures of satisfaction were collected from the American Customer Satisfaction Index (ACSI currently available on-line). A full discussion of the nature of the ACSI is provided by Fornell et al. ${ }^{27}$ Compustat was chosen because it provided an extensive range of information on both internal performance measures (sales, income, assets and retained earnings) and external performance measures (share prices and market value). Similarly, the ACSI provides sophisticated and statistically rigorous data on firm-level satisfaction. Although the data contained in ACSI cover only some 200 companies, the participating companies account for some 40 per cent of US GDP suggesting that coverage is comprehensive. The ACSI shares many features with the SCSB which has already be used in studies relating to financial performance. ${ }^{28}$ Furthermore, the characteristics of indices such as ACSI mean that they serve as appropriate measures when the objective is to explore relationships at firm level. ${ }^{29,30}$ Although the data relate only to the USA, some of the similarities between ACSI and SCSB (in terms of both the data collection methodology and the findings from data analysis) would tend to suggest that there may be some scope to generalise from the US findings to other developed economies.

To facilitate comparisons across sectors, firms were split into seven sectors, namely consumer goods (staples), consumer goods (cyclical), financial, technology, communications, utilities and transportation. To ensure that sufficient data were available to estimate sectoral level models the data for the six-year period were pooled. It was recognised that this could obscure some year on year changes in the relationship.

Evidence from the whole sample suggests that the relationship between satisfaction and profitability is reasonably stable across years $^{31}$ and the pooling was seen as justifiable to allow some insights into sectoral effects that might otherwise not be available. Table 1 presents the descriptive statistics including mean, median, standard deviation, range, minimum, maximum and sample size for the whole sample and disaggregated by sector. There is some evidence of differences between sectors but in most cases these are not substantial. Furthermore, although not reported in the table, the year on year changes in the level of ACSI were also found to be small. 
Table 1: Descriptive statistics for ACSI from 1994-1999, stratified by sector

\begin{tabular}{llllllll}
\hline Sector & Mean & Median & $\begin{array}{l}\text { Standard } \\
\text { deviation }\end{array}$ & Range & Minimum & Maximum & N \\
\hline Consumer, cyclical & 76.539 & 75.000 & 4.719 & 21.000 & 66.000 & 87.000 & 117 \\
Consumer staples & 79.194 & 81.000 & 6.347 & 30.000 & 60.000 & 90.000 & 172 \\
Financials & 71.641 & 71.000 & 5.751 & 23.000 & 61.000 & 84.000 & 39 \\
Technology & 73.656 & 74.000 & 4.397 & 24.000 & 56.000 & 80.000 & 33 \\
Communication service & 76.743 & 76.000 & 4.591 & 18.000 & 67.000 & 85.000 & 37 \\
Utilities & 74.668 & 75.000 & 4.609 & 22.000 & 62.000 & 84.000 & 134 \\
Transportation & 69.917 & 68.000 & 6.980 & 33.000 & 53.000 & 86.000 & 50 \\
\hline Pooled & 75.866 & 76.000 & 6.164 & 37.000 & 53.000 & 90.000 & 582 \\
\hline
\end{tabular}

The models were estimated by regressing a range of internal and external measures of performance on customer satisfaction. The internal performance measures used were sales, operating income, net income or loss and retained earning; the external measures were market return and share price. To accommodate the effect of accounting procedures across industries and companies of different sizes, ${ }^{32-34}$ accounting data for cross-sectional studies have to be scaled by an appropriate accounting variable in order to eliminate the possible effects of firm size. All internal financial variables employed were scaled by the total assets of the corresponding company in the corresponding period so that the size effect was eliminated. Further detail on the specification of models for external performance measures is discussed in the next section.

\section{RESULTS}

Table 2 provides the results for the aggregate pooled sample and for individual sectors for satisfaction and internal performance. The models estimated on the aggregate (all sectors) pooled data set are significant irrespective of which measure of performance is used. In each case, however, the explanatory power of the estimated model is poor suggesting that satisfaction has a significant effect on performance, but the magnitude of that effect is relatively small. When compared with other studies, ${ }^{35}$ however, the strength of the relationship does appear broadly similar.

There is considerable variation across sectors. In the technology and communications sectors, the evidence would suggest that satisfaction does not affect performance whereas in the financial sector, the evidence points to a generally strong relationship between the two. In other sectors, the results are rather more variable; although all remaining sectors provide evidence of a link between satisfaction and performance, the strength of the relationship and the magnitude of the impact appear to vary with the choice of measures of performance.

In addition to internal performance it is also desirable to consider external performance - as demonstrated by relevant stock market-based measures. In such models, the underlying premise is that estimated models seek to identify the extent to which information on customer satisfaction is of value in predicting the value for the chosen performance measure. Kothari and Zimmerman $^{36}$ suggest both price and return models should be employed in assessing the value of additional information (such as customer satisfaction in this case). 


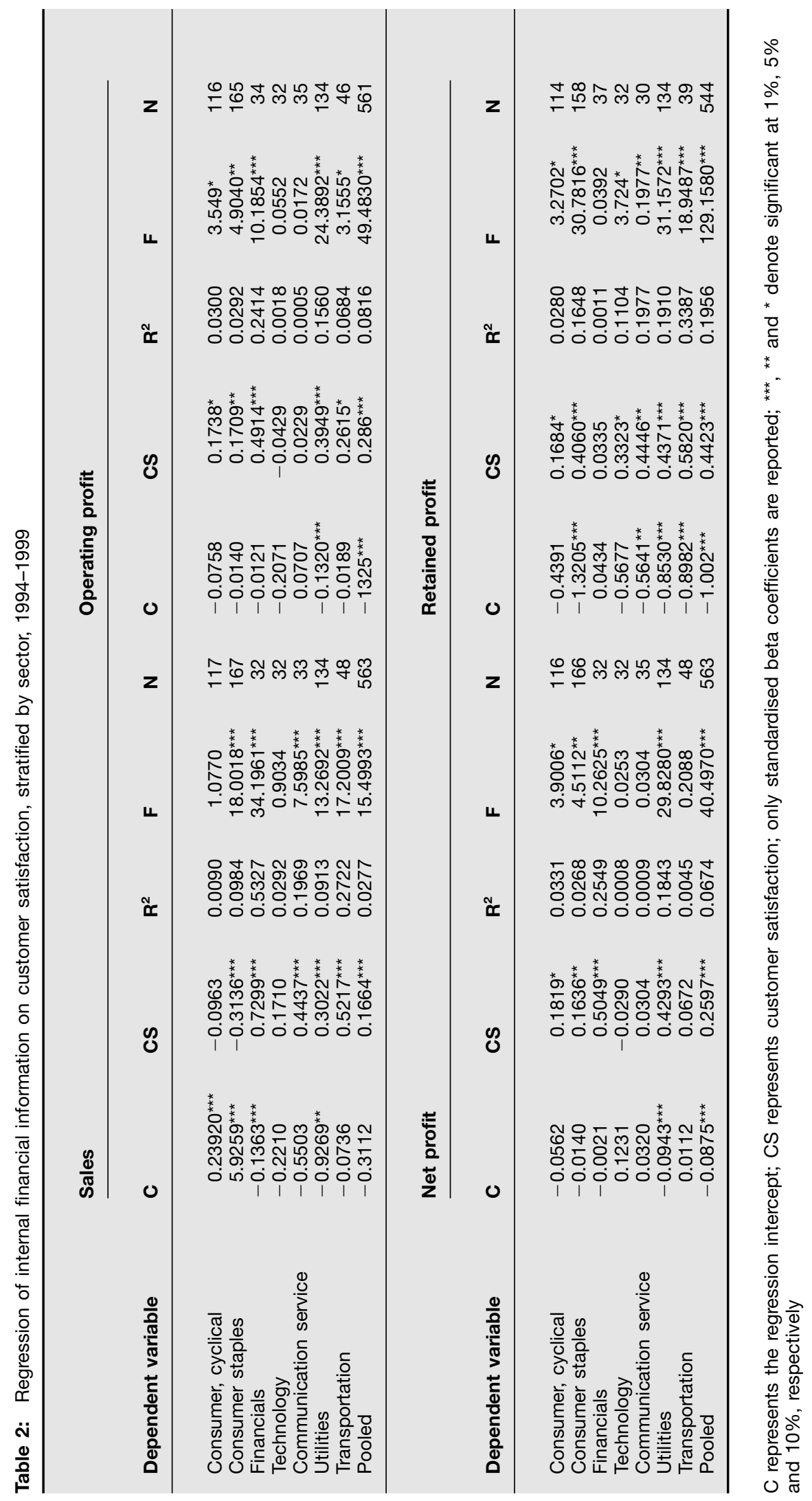




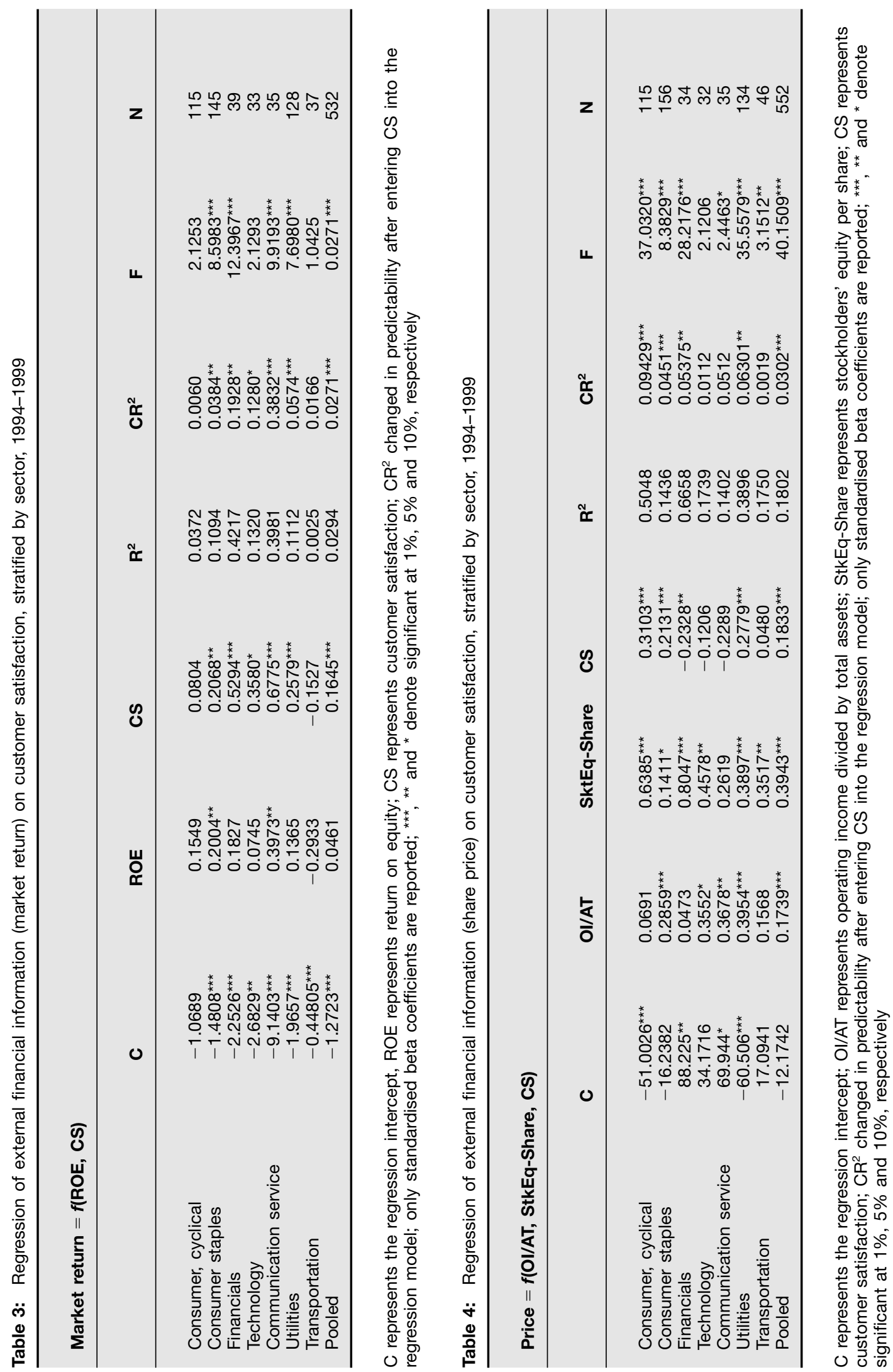




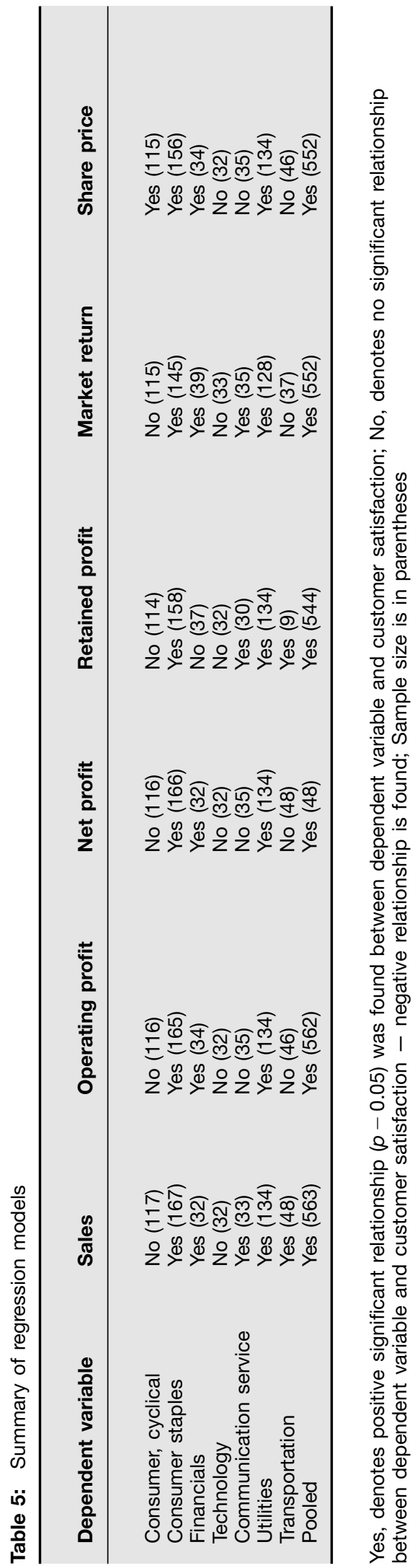


The return model uses change in the market value of a stock (increase in stock price plus dividend in time $t$ as a percentage of stock price in $t-1$ ) as the dependent variable with customer satisfaction and an earning component (in this case, return on equity) as the independent variables. The price model uses stock price as the dependent variable with operating income relative to total assets and stockholder's equity per share as independent variables along with customer satisfaction. The results for these two specifications are reported in Tables 3 and 4 respectively. Both tables include a column, $\mathrm{CR}^{2}$, which measures the change in explanatory power of the model due to the inclusion of consumer satisfaction.

For the return models, the results suggest that customer satisfaction is a significant predictor of market return for all sectors except transport and cyclical consumer goods. The relationship is only significant at 10 per cent in the case of technology. In the case of the share price models, a similar pattern emerges with consumer satisfaction again proving to be insignificant in the case of technology, communications and transportation. For both measures of external performance the relationship with satisfaction is strongest in the case of the financial sector, although the relatively small sample size suggests that this finding should be interpreted with care.

Table 5 provides a summary of the estimated models for the range of different performance measures. In general, there appears to be a high degree of consistency with respect to the impact of customer satisfaction on performance across a range of performance measures. Where there is evidence of satisfaction having an impact on internal measures of performance, it also appears to have an impact on external performance.

\section{CONCLUSIONS}

Customer satisfaction has always been of considerable interest to marketers simply because it is a key objective for the marketing process and has performance implications. Clearly, links between satisfaction and business performance are complex and there is little doubt that customer loyalty (in terms of both attitude and behaviour) plays a key role. Certainly, there is a growing body of evidence to suggest that satisfaction alone cannot deliver superior performance and that the influence of the loyalty effect is significant. Notwithstanding the role of loyalty, there are clear arguments for believing in the existence of a positive relationship between satisfaction and business performance. A range of studies have attempted to measure the relationship with mixed results. This paper has attempted to provide further evidence for the existence and strength of the satisfaction-performance relationship using a range of financial measures of business performance. Although the analysis is based only on US data, the similarity between these findings and those reported using the $\mathrm{SCSB}^{37}$ would suggest that the findings have the potential to be of relevance at least in other developed country contexts.

Using data from ACSI, the paper has compared and contrasted the impact of customer satisfaction on financial performance using both internal (firm generated) and external (market generated) measures of performance. The results indicate a high degree of consistency in terms of the impact of customer satisfaction. If customer satisfaction has a significant impact on one measure of financial performance, it tends to be significant with respect to other measures. This would suggest that the relationship between the two variables may be considered to be robust 
in that it appears to endure irrespective of which performance measure is used.

At a sectoral level, the relationship between satisfaction and performance is more variable. The reasons for this variation are not obvious but may reflect the different time frames in which the businesses operate (eg the longer-term nature of technology businesses), differences in market structures (eg high degrees of monopoly power in relation to utilities) or possibly even differences in the significance of retention and loyalty (eg the tendency for relatively higher levels of customer retention in financial services). The aggregate picture is one that supports the belief that customer satisfaction can and does have a measurable impact on financial performance and this evidence is certainly supportive of the growing interest in combining financial and non-financial measures when assessing the performance of organisations (eg Kaplan and Norton's, ${ }^{38}$ notion of balanced scorecards). The collection of sensible and appropriate customer satisfaction data will continue to be an issue but with the development of systems such as ACSI, $\mathrm{SCSB}$, there is now a well-established methodology for collecting satisfaction data at an aggregate level.

Clearly, the current analysis does not provide a definitive set of results. In particular, it has relied on pooling data over time to support the sectoral analysis and it has focused only on contemporaneous links between satisfaction and financial performance. Further analysis and exploration of the time dimension in the satisfaction performance relationship is one important area for further research. The findings reported to date do, however, provide preliminary evidence as to the potential value (in terms of financial performance) of customer satisfaction as a business objective.

\section{References}

1 Lowenstein, M. W. (1996) 'Keep them coming back', Marketing Tools, pp. 54-57, May.

2 Jusko, J. (1999) 'Tried and true', Industry Week, Vol. 248, Issue 22, pp. 78-84.

3 Oliver, R. L. (1997) 'Satisfaction: A behavioural perspective of the consumer', McGraw Hill, New York.

4 Reichheld, F. F. (1996) 'The loyalty effect: The hidden force behind growth, profits and lasting value', Harvard Business School Press, Boston.

5 Hofmeyr, J. and Rice, B. (2000) 'Commitment led marketing', Wiley, New York.

6 Oliver (1997) op. cit.

7 Anderson, E. W., Fornell, C. and Lehman, D. R. (1994) 'Customer satisfaction, market share, and profitability: Findings from Sweden', Journal of Marketing, pp. 53-66, July.

8 Anderson, E. W. and Sullivan, M. W. (1993) 'The antecedents and consequences of customer satisfaction for firms', Marketing Science, Vol. 12, pp. 125-143, Spring.

9 Fornell, C. (1992) 'A national customer satisfaction barometer: The Swedish experience', Journal of Marketing, pp. 1-21, January.

10 Taylor, S. A. and Baker, T. L. (1994) 'An assessment of the relationship between service quality and customer satisfaction in the formation of consumers' purchase intentions', Journal of Retailing, Vol. 70, No. 2, pp. 163-178.

11 Reichheld, F. F. and Sasser, W. E. (1990) 'Zero defections: Quality comes to services', Harvard Business Review, pp. 105-111, September-October.

12 Bearden, W. O. and Teel, J. E. (1982) 'Selected determinants of customer satisfaction with problem resolution', Journal of Marketing Research, pp. 21-28, February.

13 LaBarbera, P. A. and Mazursky, D. (1983) 'A longitudinal assessment of consumer satisfaction/dis-satisfaction: The dynamic aspect of the cognitive process, Journal of Marketing Research, Vol. 20, pp. 393-404.

14 Verbeke, W. J. M. I., Farris, P. and Thurik, R. (1995) 'Consumer response to the preferred brand out-of-stock situation', Working Paper from Tinbergen Institute Rotterdam.

15 Ennew, C. T. and Binks, M. R. (1996) 'Service quality, customer satisfaction and customer retention', British Journal of Management, Vol. 7, pp. 219-230.

16 Peters, T. and Waterman, R. H. (1982) 'In search of excellence: Lessons from America's best run companies', Harper Row, New York.

17 Mahajan, V., Sharma, S. and Netemeyer, R. G. (1992) 'Should we expect the Baldrige Award to predict a company's financial success?', Technological Forecasting and Social Change, Vol. 42, pp. 325-334.

18 Aaker, D. A. and Jacobson, R. (1994) 'The financial information content of perceived quality', Journal of Market Research, pp. 191-201, May.

19 Anderson, Fornell and Lehman (1994) op. cit.

20 Loveman, G. W. (1998) 'Employee satisfaction, customer loyalty, and financial performance: An 
empirical examination of the service profit chain in retail banking', Journal of Service Research, Vol. 1, No. 1, pp. 18-31.

21 Ittner, C. D. and Larcker, D. F. (1998) 'Are non-financial measures leading indicators of financial performance? An analysis of customer satisfaction', Working Paper, University of Pennsylvania.

22 Reichheld (1996) op. cit.

23 Hofmeyer and Rice (2000) op. cit.

24 Zeithaml, V. A., Berry, L. L. and Parasuraman, A. (1996) 'The behavioural consequences of service quality', Journal of Marketing, Vol. 60, pp. 31-46.

25 Mittal, B. and Lasser, W. M. (1998) 'Why do customers switch? The dynamics of satisfaction versus loyalty', Journal of Services Marketing, Vol. 12, No. 3, pp. 177-194.

26 de Ruyter, K., Wetzels, M. and Bloemer, J. (1998) 'On the relationship between perceived service quality, service loyalty and switching costs',

International Journal of Service Industry Management, Vol. 9, No. 5, pp. 436-453.

27 Fornell, C., Johnson, M. D., Anderson, E. W., Cha, J. and Bryant, B. E. (1996) 'The American customer satisfaction index: Nature, purpose and findings', Journal of Marketing, Vol. 60, pp. 7-18, October.
28 Anderson, Fornell and Lehman (1994) op. cit.

29 Fornell (1992) op. cit.

30 Grant, L. (1998) 'Your customers are telling the truth', Fortune, Vol. 137, No. 3, pp. 167-174.

31 Yeung, M. C. H. and Ennew, C. T. (2000) 'From customer satisfaction to profitability', Journal of Strategic Marketing, Vol. 10, pp. 313-326.

32 Zimmerman, J. L. (1983) 'Taxes and firm size', Journal of Accounting and Economics, pp. 119-149, August.

33 Watts, R. L. and Zimmerman, J. L. (1986) 'Positive accounting theory', Prentice-Hall, New Jersey.

34 Moses, O. D. (1987) 'Income smoothing and incentives: Empirical tests using accounting changes', The Accounting Review, pp. 358-377, April.

35 eg Ittner and Larcker (1998) op. cit.

36 Kothari, S. and Zimmerman, J. (1995) 'Price and return models', Journal of Accounting and Economics, Vol. 20, pp. 155-192.

37 See, for example, Anderson, Fornell and Lehman (1994) op. cit.

38 Kaplan, R. S. and Norton, D. P. (1991) 'The balanced scorecard - Measures that drive performance', Harvard Business Review, pp. 71-79, January/February. 